\title{
IMPLEMENTASI ETIKA BISNIS ISLAM DALAM PERBANKAN SYARIAH
}

\author{
Husnul Khotimah Sylvia, Rizki Annisa, Nurafifah zahra, \\ khusnulkhatimah007@yahoo.co.id, Kikirizki2844@gmail.com, \\ Nurafifah.zahra2603@gmail.com.
}

\begin{abstract}
Abstrak :
The market share of Islamic banking in Indonesia is still relatively small when compared to conventional market share, but Islamic banking has a significant annual growth rate. The development of this sharia market share is encouraging but has not yet been followed by the application of Islamic business ethics principles to the maximum. Disclosure of ethical information of Islamic banks both quantitative and qualitative (moral and material aspects) is absolutely essential for Islamic banks because Islamic banks have a legal responsibility to show that Islamic banks have truly applied the principles of Islamic business ethics in their operational activities and also in providing guidance to the stakeholders (consisting of savings customers, shareholders, investors, bonds, respondent banks, regulators, company employees, suppliers, and the community environment) in making economic decisions in an effort to realize public accountability

Pangsa pasar perbankan syariah di Indonesia masih relatif kecil bila di bandingkan dengan pangsa pasar konvensional namun perbankan syariah memiliki tingkat pertumbuhan tahunan yang cukup signifikan. Perkembangan pangsa pasar syariah ini cuckup menggembirakan namun belum diikuti dengan penerapan prinsip etika bisnis islam yang yang maksimal. Pengungkapan informasi etis bank syaraih baik yang bersifat kuantitatif maupun kualitatif (aspek moral maupun material) adalah hal yang mutlak bagi bank syariah sebab secara yuridis bank syariah memiliki tanggung jawab untuk menunjukan bahwa bank syariah telah benar-benar menerapkan prinsip etika bisnis islam dalam kegiatan oprasionalnya dan juga dalam memberikan panduan kepada para pihak pemangku kepentingan atau stakeholder (yang terdiri dari nasabah penabung, pemegang saham, investor, obligasi, bank responden, regulator, pegawai perseroan, pemasok, dan lingkungan masyarakat) dalam membuat keputusan-keputusan ekonomi dalam upaya mewujudkan akuntabilitas publik.
\end{abstract}

Keyword : Implementasi, economic, Islamic business 


\section{A. PENDAHULUAN}

Penerapan etika dalam berbagai aspek kehidupan saat ini, sangat mengkhawatirkan dan miris dibuatnya, kondisi saat ini manusia hampir melupakan tatanan moral, etika maupun pada tahap spiritual dalam kehidupan sehari-harinya dalam berinteraksi dengan alam semesta, baik pada kerabat, social masyarakat, lingkungan, bahkan ketiadaan adab kepada Rasulullah dan penciptanya sendiri, Allah swt. Penomena krisis adab ini sangat mudah kita jumpai di setiap harinya dalam pergaulan kehidupan bermasyarakat, baik dalam kehudipam social media, social masyarakat, pada transaksi ekonomi dan bisnis, dan interaksi langsung mapun tidak langsung lainnya. Sedangkan Indonesia khususnya memiliki mayoritas muslim terbanyak di dunia, sudah seharusnya bercermin pada ajaran Islam yang kaffah, murni dan sesungguhnya. Dalam Islam sudah banyak sekali Al-Qur'an maupun Al-Hadits menerangkan tentang pentingnya adab atau etika, diantaranya adalah : Sesungguhnya orang yang terbaik dari kalian adalah orang yang terbaik akhlaknya“"1

Dalam perkembangan ekonomi pada saat ini, semakin marak dengan penerapan sistem perekonomian yang berbeda pada setiap negara. Pada pelaksanaan dan penerapan perekonomian ini hendaknya memberikan tanggung jawab dan kewajiban yang seimbang pada kelestarian dan kesetaraan seluruh manusia. Dengan demikian penerapan etika dalam pelaksanaan perekonomian pun dirasakan perlu lebih ditingkatkan. Bisnis tidak hanya dipengaruhi oleh situasi ataupun kondisi ekonomi saja, namun juga oleh perubahan-perubahan sosial, politik, ekonomi dan teknologi serta pergeseran sikap dan cara pandang stakeholder-nya.

Islam tidak akan membiarkan begitu saja seseorang bekerja sesuka hati untuk mencapai tujuan dan keinginannya dengan menghalalkan segala cara seperti melakukan penipian, lecurangan, sumpah palsu, riba dan perbuatan batil lainnya. Tetapi dalam islam 
diberikan suatu batasan atau garis pemisah antara yanga boleh atau yang tidak boleh, yang benar atau yang salah, serta yang halal atau yang haram. Batasan atau garis pemisah inilah yang dikenal dengan istilah etika. ${ }^{2}$

Menurut Mustaq Ahmad perilaku bisnis yang benar adalah yang sesuai dengan ajaran Al- Qur'an dan implementasinya tidak hanya baik terhadap sesama manusia, tetapi juga harus selalu dekat dengan Allah SWT. Sedangkan menurut Puspo Wardoyo didalam bukunya yang berjudul "Membentuk Entrepreneur Muslim”, bisnis yang menguntungkan harus mengandung tiga elemen dasar, yaitu: (1). Menanam investasi yang terbaik; (2). Membuat keputusan yang logis, sehat dan masuk akal; (3). Menerapkan prilaku yang baik. Pera pelaku bisnis sangat peting untuk menyadari bahwa praktik bisnisnya tidak lah berarti bebas nilai. Dengan peringatan tersebut para pelaku bisnis akan secara langsung menerapkan bisnisnya secara halal dan sah, melalui keputusan yang tepat yang di imbangi dengan perilaku yang sesuai syariah. Namun praktek-praktek bisnis yang dilakukan pada saat ini masih diragukan ke syariahan nya. Banyak yang telah meninggalkan nilai-nilai atau etika islam hanya untuk mencari laba sebesar-besarnya. Demikian pula dalam melaksanakan aktivitas ekonomi, nilai-nilai islam senantiasa menjadi landasan utamanya. Semua praktek bermuamalah diperbolehkan, kecuali yang dilarang dalam Al-Qur'an. Hal tersebut memberikan ruang gerak yang luas bagi umat islam untuk melakukan aktivitas ekonominya sehingga dapat meningkatkan taraf hidupnya. ${ }^{3}$

Masalah etika merupakan salah satu fondasi yang harus diciptakan dan dimiliki oleh setiap pelaku bisnis etika pada dasarnya adalah standar atau moral yang menyangkut benar dan salah. Etika dalam ajaran islam menuntun seluruh aspek perilaku kehidupan manusia,baik permasalahn bisnis maupun aktivitas sehari-hari. Bisnis yang baik adalah bisnis yang berlandaskan etika, pelaku bisnis muslim hendaknya memiliki kerangka etika bisnis yang kuat sehingga dapat menciptakan aktivitas bisnis yang baik dan berkah. ${ }^{4}$ 
Salah satu bisnis syariah yaitu perbankan syariah. Penerimaan masyarakat terhadap keberadaan industri perbankan syariah di indonesia pada saat ini terus berkembang baik dan positif hal ini dikarenakan sebagian masyarakat telah menyadari dalam berbisnis secara syariah. Tren pertumbuhan perbankan syariah menunjukan adanya kenaikan dan cenderung positif. Jika dibandingkan dengan tren pertumbuhan perbakan konvensional masih kalah cepat perbankannya, tetapi data dari sumber yang sama menerangkan dari waktu kewaktu LDR (Loan Deposit Ratio) perbankan syariah bisa ditekan, sedangkan LDR pada bank konvensional semakin lama semakin naik (menandakan bahwa bank konvensional masih punya masalah utang jangka pendek). Kondisi diatas menyebabkan adanya kenaikan minat bank-bank konvensional untuk membuka cabang atau unit syariah. Salah satu tujuan nya adalah agar dapat ikut berperan serta dan berkontribusi dalam memberi layanan keuangan syariah kepada masyarakat. Berdasarkan data publikasi bank syariah senter indonesia (2016) hingga saat ini indonesia telah memiliki bank umum syariah sejumlah 11, Unit Usaha Syariah (UUS) berjumlah 24 dan layanan syariah (Office chaneling) berjumlah 31 yang tersebar dibeberapa provinsi. ${ }^{5}$

\section{B. PEMBAHASAN}

\section{Etika Dalam Perspektif Islam}

Istilah etika secara teoritis dapat dibedakan menjadi dua pengertian. Pertama, etika secara bahasa berasal dari bahasa yunani yaitu ethos yang artinya kebiasaan (custom) atau karakter (character). Dalam pengertian ini, etika berkaitan dengan kebiasaan hidup yang baik, baik pada diri seseorang maupun pada suatu masyarakat atau kelompok masyarakat yang di wariskan dari satu orang ke orang yang lain atau dari satu generasi ke generasi yang lain. Kedua, secara istilah etika merupakan studi sistematis tentang tabiat konsep nilai, baik, buruk, halus, benar, salah, dan lain sebagainya dan prinsip- 
prinsip umum yang membenarkan kita untuk mengaplikasikan atas apa saja. Disni etika dapat di maknai sebagai dasar moralitas seseorang dan disaat bersamaan juga sebagai filsufnya dalam berprilaku. ${ }^{6}$

" Etika dalam bahasa arab adalah adab atau Akhlak Islamiyah (إسلام ية أخلاق (" adalah etika dan moral yang dianjurkan di dalam ajaran Islam yang tercantum di dalam Al-Quran dan Sunnah, dengan mengikuti contoh dari teladan Nabi Muhammad, yang di dalam akidah Islamiyah dinyatakan sebagai manusia yang paling sempurna akhlaknya. Akhlak tersebut terbagi menjadi dua yaitu akhlak yang terpuji (akhlaq mahmudah) dan akhlak yang tercela ("akhlaq madzmumah").

Pengertian akhlak menurut Imam Al-Qurthubi adalah $^{7}$ : sifat-sifat seseorang, sehingga dia dapat berhubungan dengan orang lain. Akhlak ada yang terpuji dan ada yang tercela. Secara umum makna akhlak yang terpuji adalah engkau berhias dengan aklak yang terpuji ketika berhubungabn dengan sesama, dimana engkau bersikap adil dengan sifat-sifat terpuji dan tidak lalim karenanya. Sedangkan secara rinci adalah memaafkan, berlapang dada, dermawan, sabar, menahan penderitaan, berkasih sayang, memenuhi kebutuhan hidup orang lain, mencintai, bersikap lemah lembut dan sejenis itu. Sedangkan Akhlak yang tercela adalah sifat-sifat yang berlawanan dengan itu.

Dalam perspektif umum, etika di artikan sebagai perangkat yang mengatur tingkahlaku manusia. Etika memberika petunjuk bagi manusia mengenai apa yang harus dilakukan dan apa yang tidak boleh dilakukan. Dengan demikian, keberadaan etika aka membuat kedamaian dan ketentraman dalam hidup manusia. Sedangkan dalam perspektif islam, etika sering di katkan dengan istilah akhlak (khuluk) yang kurang lebih juga bermakna sama dengan etika, yakni pedoman mengenai apa yang boleh untuk dilakukan dan apa yang tidak boleh dilakukan. Meskipun memiliki definisi yang hampir sama, etika 
dan akhlak memiri sumber yang sama. Etika bersumber pada kebiasaan atau adat istiada yang di anggap baik, sedangkan akhlak bersumber pada Al-Qur'an dan hadis ${ }^{8}$.

Maka etika bisnis Islam merupakan salah satu bentuk implementasi niali-nilai keislaman didalam aktivitas bisnis. Etika bisnis Islam bersumber langsung pada firman Allah diantaranya adalah:

"(yaitu) orang-orang yang menafkahkan (hartanya), baik di waktu lapang maupun sempit, dan orang-orang yang menahan amarahnya dan memaafkan (kesalahan) orang. Allah menyukai orang-orang yang berbuat kebajikan." (QS.Ali-Imran: 134).

Kemudian banyak kita jumpai juga pembahasan akhlak tersebut pada hadist Nabi diantaranya adalah:

"Sesungguhnya orang yang terbaik dari kalian adalah orang yang terbaik akhlaknya“"9 "Kaum Mukminin yang paling sempurna imannya adalah yang paling baik akhlaknya (di antara mereka) ${ }^{10}$. "Pergaulilah manusia dengan akhlak yang mulia “11

Etika, adab, akhlak tersebut kemudian diadopsi menjadi tata nilai dan norma. Tata

nilai dan norma itu yang mengatur etika, adab, akhlak atau tingkahlaku seorang muslim yang harus di jaga, dipelihara, dan diimplementasikan dalam kehidupan sehari- hari di masyarakat, disemua aspek kehidupan, termasuk pada tata nilai dan norma dalam bisnis dan ekonomi.

\section{Prinsip Etika Bisnis Dalam Perspektif Islam}

Islam mengajarkan banyak hal tentang kehidupan bermasyarakat, dan Islam juga tidak membiarkan begitu saja seseorang bekerja sesuka hati untuk mencapai tujuan dan keinginannya dengan menghalalkan segala cara seperti melakukan penipuan, kecurangan, sumpah palsu, riba, menyuap dan perbuatan batil lainnya. Tetapi dalam Islam diberikan suatu batasan atau garis pemisah antara yang boleh dan yang tidak boleh, yang benar dan salah serta yang halal dan yang haram. Batasan atau garis pemisah inilah yang dikenal dengan istilah etika. Prilaku dalam berbisnis atau berdagang juga tidak luput dari adanya 
nilai moral atau nilai etika bisnis. Penting bagi para pelaku bisnis untuk mengintegrasikan dimensi moral dan spiritual, adab dan etika ke dalam kerangka atau ruang lingkup bisnis di tengah masyarakat.

Kesadaran masyarakat saat ini terhadap etika dalam berbisnis, sedikit mengalami krisis, sehingga berpengaruh pada krisis multi dimensi dalam kehidupan masyarakat. Pentingnya keterkaitan faktor-faktor etika dalam bisnis, harus segera mungkin ditekankan dalam aplikasi kehidupan sehari-hari pada semua sektor. Sesungguhnya dalam hal seluruh pelaksanaan kehidupan telah di atur dalam pandangan ajaran Agama Islam untuk mengatur seluruh kehidupan manusia termasuk dalam kaitannya pelaksanaan perekonomian dan bisnis. Dalam ajaran Islam memberikan kewajiban bagi setiap muslim untuk berusaha semaksimal mungkin untuk melaksanakan syariah atau aturan yang sudah ditentukan dalam Al-Qur'an dan Al-Hadits di segala aspek kehidupan termasuk di dalamnya aturan bermuamalah (usaha dan bisnis) yang merupakan jalan dalam rangka mencari kehidupan. Pada hakikatnya tujuan penerapan aturan (syariah) dalam ajaran Islam di bidang muamalah tersebut khususnya perilaku bisnis adalah agar terciptanya pendapatan (rizki) yang berkah, sehingga akan mewujudkan pembangunan manusia yang berkeadilan dan stabilisasi untuk mencapai pemenuhan kebutuhan, kesempatan kerja penuh dan distribusi pendapatan yang merata tanpa harus mengalami ketidakseimbangan yang berkepanjangan di masyarakat ${ }^{12}$

Etika bisnis dalam Islam adalah sejumlah perilaku etis bisnis (akhlaq al Islamiyah) yang dibungkus dengan nilai-nilai syariah yang mengedepankan halal dan haram. Jadi perilaku yang etis itu ialah perilaku yang mengikuti perintah Allah dan menjauhi larangnya. Dalam Islam etika bisnis ini sudah banyak dibahas dalam berbagai literatur dan sumber utamanya adalah Al-Quran dan sunnaturrasul. Pelaku-pelaku bisnis diharapkan bertindak secara etis dalam berbagai aktivitasnya. Kepercayaan, keadilan dan 
kejujuran adalah elemen pokok dalam mencapai suksesnya suatu bisnis di kemudian hari. Bisnis dipengaruhi bukan hanya oleh situasi dan kondisi ekonomi, melainkan juga oleh perubahan-perubahan sosial, politik, ekonomi dan teknologi serta pergeseran-pergeseran sikap dan cara pandang para stakeholdersnya. Bisnis tidak dipandang secara sempit dengan tujuan memaksimalkan nilai (ekonomi) bagi pemiliknya, tetapi bisnis harus tetap mempertimbangkan segala sesuatu yang mempengaruhi pencapaian tujuan tersebut. Tujuan bisnis untuk memaksimumkan keuntungan bagi pemilik perusahaan dapat dicapai secara lebih baik yaitu dengan memperhatikan manusia, memanusiakan manusia dan melakukan langkahlangkah yang harmonis dengan seluruh stake holders, seluruh partisipan dan lingkungan tempat perusahaan berada.

Istilah bisnis dalam Al-Qur'an yaitu al-tijarah dan dalam bahasa arab tijaraha, berawal dari kata dasar t-j-r, tajara, tajranwatijarata, yang bermakna berdagang atau berniaga. At-tijaratunwalmutjar yaitu perdagangan, perniagaan (menurut kamus almunawwir). Menurut ar-Raghib al-Asfahani dalam al-mufradat fi gharib al-Qur'an, atTijarah bermakna pengelolaan harta benda untuk mencari keuntungan. Menurut Ibnu Farabi, yang dikutip ar-Raghib, fulanuntajirun bi kadza, berarti seseorang yang mahir dan cakap yang mengetahui arah dan tujuan yang diupayakan dalam usahanya ${ }^{13}$.

Prinsip-prinsip etika bisnis menurut AlQur'an : Pertama, melarang bisnis yang dilaku kan dengan proses kebatilan (QS. 4:29). Bisnis harus didasari kerelaan dan keterbukaan antara kedua belah pihak dan tanpa ada pihak yang dirugikan. Orang yang berbuat batil termasuk perbuatan aniaya, melanggar hak dan berdosa besar (QS.4:30). Sedangkan orang yang menghindarinya akan selamat dan mendapat kemuliaan (QS.4:31). Kedua, Bisnis tidak boleh mengandung unsur riba (QS. 2:275). Ketiga, kegiatan bisnis juga memiliki fungsi sosial baik melalui zakat dan sedekah (QS. 9:34). Pengembangan harta tidak akan terwujud kecuali melalui interaksi antar sesama dalam berbagai 
bentuknya. Keempat, melarang pengurangan hak atas suatu barang atau komoditas yang didapat atau diproses dengan media takaran atau timbangan karena merupakan bentuk kezaliman (QS. 11:85), sehingga dalam praktek bisnis, timbangan harus disempurnakan (QS. 7:85, QS. 2:205). Kelima, menjunjung tinggi nilai-nilai keseimbangan baik ekonomi maupun sosial, keselamatan dan kebaikan serta tidak menyetujui kerusakan dan ketidakadilan. Keenam, pelaku bisnis dilarang berbuat zalim (curang) baik bagi dirinya sendiri maupun kepada pelaku bisnis yang lain (QS. 7:85, QS.2:205).

Adapun Sri Nawatmi ${ }^{14}$, mengulas pada lima belas prinsip mengenai etika bisnis menurut Rasulullah saw, yaitu: Pertama, bahwa prinsip penting dalam bisnis adalah kejujuran. Dalam doktrin Islam, kejujuran merupakan syarat fundamental dalam kegiatan bisnis. Rasulullah sangat intens menganjurkan kejujuran dalam aktivitas bisnis. Dalam tataran ini, beliau bersabda: "Tidak dibenarkan seorang muslim menjual satu jualan yang mempunyai aib, kecuali ia menjelaskan aibnya” (H.R. Al-Quzwani). "Siapa yang menipu kami, maka dia bukan kelompok kami” (H.R. Muslim). Rasulullah sendiri selalu bersikap jujur dalam berbisnis. Beliau melarang para pedagang meletakkan barang busuk di sebelah bawah dan barang bagus di bagian atas. Kedua, kesadaran tentang pentingnya kegiatan sosial dalam bisnis. Pelaku bisnis menurut Islam, tidak hanya sekedar mengejar keuntunganyang maksimal, seperti yang diajarkan pada ekonomi kapitalis, tetapi juga berorientasi kepada sikap ta'awun (menolong orang lain) sebagai implikasi sosial kegiatan bisnis. Tegasnya, berbisnis, bukan mencari untung dalam materi semata, tetapi juga didasari kesadaran memberi kemudahan bagi orang lain dengan menjual barang.

Ketiga, tidak melakukan sumpah palsu. Nabi Muhammad saw sangat intens melarang para pelaku bisnis melakukan sumpah palsu dalam melakukan transaksi bisnis Dalam sebuah HR. Bukhari, Nabi saw bersabda, "Dengan melakukan sumpah palsu, barang-barang memang terjual, tetapi hasilnya tidak berkah”. Dalam HR. Abu Dzar, 
Rasulullah saw mengancam dengan azab yang pedih bagi orang yang bersumpah palsu dalam bisnis, dan Allah tidak akan memperdulikannya nanti di hari kiamat (H.R. Muslim). Praktek sumpah palsu dalam kegiatan bisnis saat ini sering dilakukan, karena dapat meyakinkan pembeli, dan pada gilirannya meningkatkan daya beli atau pemasaran. Namun, harus disadari, bahwa meskipun keuntungan yang diperoleh berlimpah, tetapi hasilnya tidak berkah.

Keempat, ramah-tamah . Seorang palaku bisnis, harus bersikap ramah dalam melakukan bisnis. Nabi Muhammad saw mengatakan, "Allah merahmati seseorang yang ramah dan toleran dalam berbisnis." (HR.Bukhari dan Tarmizi). Kelima, tidak boleh berpura-pura menawar dengan harga tinggi, agar orang lain tertarik membeli dengan harga tersebut. Sabda Nabi Muhammad, "Janganlah kalian melakukan bisnis najas (seorang pembeli tertentu, berkolusi dengan penjual untuk menaikkan harga, bukan dengan niat untuk membeli, tetapi agar menarik orang lain untuk membeli)"

Keenam, tidak boleh menjelekkan bisnis orang lain, agar orang membeli kepadanya. Nabi Muhammad Saw bersabda, "Janganlah seseorang di antara kalian menjual dengan maksud untuk menjelekkan apa yang dijual oleh orang lain" (H.R. Muttafaq 'alaih). Ketujuh, tidak melakukan ihtikar. Ihtikar ialah menumpuk dan menyimpan barang dalam waktu tertentu, dengan tujuan agar harganya suatu saat menjadi naik dan keuntungan besar pun diperoleh. Rasulullah melarang keras perilaku bisnis semacam itu. Kedelapan, takaran, ukuran dan timbangan yang benar. Dalam perdagangan, timbangan yang benar dan tepat harus benar-benar diutamakan. Firman Allah: "Celakalah bagi orang yang curang, yaitu orang yang apabila menerima takaran dari orang lain, mereka minta dipenuhi, dan apabila mereka menakar atau menimbang untuk orang lain, mereka mengurangi” ( QS. 83: 112). 
Kesembilan, Bisnis tidak boleh menggangu kegiatan ibadah kepada Allah. Firman Allah, "Orang yang tidak dilalaikan oleh bisnis lantaran mengingat Allah, dan dari mendirikan shalat dan membayar zakat. Mereka takut kepada suatu hari yang hari itu, hati dan penglihatan menjadi goncang”. Kesepuluh, membayar upah sebelum keringat karyawan kering. Nabi Muhammad Saw bersabda, "Berikanlah upah kepada karyawan, sebelum kering keringatnya”. Hadist ini mengindikasikan bahwa pembayaran upah tidak boleh ditundatunda. Pembayaran upah harus sesuai dengan kerja yang dilakukan.

Kesebelas, tidak ada monopoli. Salah satu keburukan sistem ekonomi kapitalis ialah melegitimasi monopoli dan oligopoli. Contoh yang sederhana adalah eksploitasi (penguasaan) individu tertentu atas hak milik sosial, seperti air, udara dan tanah dan kandungan isinya seperti barang tambang dan mineral. Individu tersebut mengeruk keuntungan secara pribadi, tanpa memberi kesempatan kepada orang lain. Ini dilarang dalam Islam. Keduabelas, tidak boleh melakukan bisnis dalam kondisi bahaya (mudharat) yang dapat merugikan dan merusak kehidupan individu dan sosial. Misalnya, larangan melakukan bisnis senjata di saat terjadi chaos (kekacauan) politik. Tidak boleh menjual barang halal, seperti anggur kepada produsen minuman keras, karena ia diduga keras, mengolahnya menjadi miras. Semua bentuk bisnis tersebut dilarang Islam karena dapat merusak esensi hubungan sosial yang justru harus dijaga dan diperhatikan secara cermat. Ketiga belas, komoditi bisnis yang dijual adalah barang yang suci dan halal, bukan barang yang haram, seperti babi, anjing, minuman keras, ekstasi, dsb. Nabi Muhammad Saw bersabda, "Sesungguhnya Allah mengharamkan bisnis miras, bangkai, babi dan “patung-patung”(HR. Jabir). Keempatbelas, bisnis dilakukan dengan suka rela, tanpa paksaan. Firman Allah, "Hai orangorang yang beriman, janganlah kamu saling memakan harta sesamamu dengan cara yang batil, kecuali dengan jalan bisnis yang berlaku dengan suka-sama suka di antara kamu" (QS. 4: 29). Kelimabelas, segera melunasi kredit yang 
menjadi kewajibannya. Rasulullah memuji seorang muslim yang memiliki perhatian serius dalam pelunasan hutangnya. Sabda Nabi Saw, "Sebaikbaik kamu, adalah orang yang paling segera membayar hutangnya" (H.R. Hakim). Keenambelas, Memberi tenggang waktu apabila pengutang belum mampu membayar. Sabda Nabi Saw, "Barang siapa yang menangguhkan orang yang kesulitan membayar hutang atau membebaskannya, Allah akan memberinya naungan di bawah naunganNya pada hari yang tak ada naungan kecuali naunganNya. (HR. Muslim). Ketujuhbelas, bahwa bisnis yang dilaksanakan bersih dari unsur riba. Firman Allah, "Hai orang-orang yang beriman, tinggal kanlah sisa-sisa riba jika kamu beriman (QS. Al-Baqarah: 278). Pelaku dan pemakan riba dinilai Allah sebagai orang yang kesetanan (QS. 2: 275). Oleh karena itu Allah dan Rasulnya mengumumkan perang terhadap riba.

Namun secara umum prinsip etika bisnis Islam menurut Qardhawi (2001) harus memenuhi persyaratan sebagai berikut ${ }^{15}$ :

1. Aqidah, dengan adanya penyerahan diri kepada Allah SWT maka pelaku bisnis akan selalu menjaga perbuatannya dari hal-hal yang dilarang oleh syariah.

2. Sidiq, sifar sidiq mendorong rasa tanggung jawab atas segala perbuatan dalam hal muamalah.

3. Fathanah, sifat fathanah ini mendorong kearifan berfikirdan bertindak sehingga keputusan yang dihasilkan menunjukkan profesionalisme yang didasarkan sikap akhlaq sepereti akhlaq Rasullulah SAW.

4. Amanah/jujur, hubungan bisnis yang dilandasi kejujuran memunculkan kepercayaan yang merupakan hal yang paling mendasar dari semua hubungan bisnis.

5. Tabligh, kemampuan komunikasi dalam kata tabligh menunjukan proses menyampaikan sesuatu untuk memepengaruhi orang lain melalui perkataan yang baik. 
6. Tidak melakukan praktek bisnis yang bertentangan dengan syariah, antara lain:

a) Produk dan jasa yang dijual haram.

b) Gharar, adalah salah satu jual beli yang mengandung unsur penipuan dan akad transaksinya tidak jelas.

c) Al-Gabn dan Tadlis, gharar adalah harga yang di tetapkan jauh dari rata-rata yang ada baik lebih rendah maupun lebih tinggi sedangkan tadlis adalah penipuan dengan menutupi kecacatan sebuah barang yang akan di jual.

d) Riba, riba jual beli yaitu riba fadhl adalah kelebihan yang di peroleh dalan transaksi tukar menukar barang.

e) Ihtikar, adalah menimbun barang dengan harapan mendapatkan harga tinggi di kemudian hari.

f) Mengurangi timbangan atau takaran.

\section{Etika Bisnis Islam Dalam Perbankan Syariah}

Implementasi atau penerapan terhadap prinsip etika bisnis Islam dalam praktik perbankan syariah merupakan persyaratan mutlak yang harus dipenuhi menurut tuntunan syariat agama Islam dan sebagai identitas pembeda antara bank syariah dengan bank konvensional sehingga apabila perbankan syariah tidak menerapkan prinsip etika bisnis Islam secara memadai maka akan kehilangan nilai lebih yang dimilikinya bila dibandingkan dengan bank konvensional, dan pada akhirnya dapat mengancam kelangsungan hidup perbankan syariah di masa depan. Mengingat urgensi penerapan prinsip etika bisnis Islam pada industri perbankan syariah.

Bank syariah merupakan bank modern yang melakukan kegiatan operasi sepenuhnya sesuai dengan syariah hukum islam berdasarkan pada Al-Qur'an dan sunnah Rasulullah SAW yang menekankan pentingnya implementasi prilaku etis dalam segala aspek kehidupan manusia, termasuk bisnis. 
Yaya, Martawireja, dan Abdurahim, dalam tulisannya ${ }^{16}$ dalam dunia perbankan syariah terdapat beberapa lembaga-lembaga pendukung syariah di tingkat internasioanal Accounting and Auditing antara lain: accounting and auditing organization of islamic financial institution (AAOIFI), islamic development bank (IDB), international islamic financial market, islamic financial services board (IFSB), general council of islamic bank and financial institution, islamic international rating agency (IIRA), liquiditi managemen center (LMC) and international islamic center for reconciliation and kommercial arbitration (IICRCA). Diantar berbagai lembaga tersebut, yang memberikan pengaruh terbesar terhadap penerapan etika bisnis islam dalam perbankan syariah adalah AAOIFI yang hingga tahun 2009 telah menerbitkan tiga standar akutansi, lima standar audit, enam standar tata kelola, dua standar kode etik, dan tiga puluh standar syariah dengan tujuan mengharmonisasikan konsep dan penerapan fatwa-fatwa diantara dewan pengawas syriah di berbagai bank syariah untuk menghindari kontradiksi dan inkonsistensi mengingat ada banyak mazhab yang berkembang. Standar AAOIFI telah menjadi acuan yang bersifat wajib di beberapa negara, termaksut indonesia. AAOIFI juga mewujudkan terselenggaranya program sertifikasi akuntan publik syariah (certified islamic public acountant atau CIPA) dalam rangka peningkatan audit syariah bagi perbankan syariah.

Lembaga kedua yang tidak kalah penting dalam mendukung penerapan prinsip etika bisnis islam bagi perbankan syariah adalah IDB. IDB adalah lembaga keuangan internasional yang didirikan berdasarkan hasil deklarasi konferensi para mentri keuangan negara- negra muslim di Jeddah pada tahun 1973 yang bertujuan untuk mendorong kemajuan pembangunan ekonomi dan sosial negara-negara anggota dan komunitas muslim berdasar prinsip syriah islam. dukungan terbesar IDB terhadap penerapan prinsip etika bisnis islam dalam industri perbangkan syariah adalah dalam bentuk fasilitas 
berbagai penelitian dalam bidang ekonomi, keuangan, dam perbankan syariah melalui lembaga islamic research and training institute (IRTI) dan pemyertaan modal maupun kepemilikan saham pada bank syariah pada berbagai negara ${ }^{17}$.

Selain lembaga-lembaga tingkat internasional, ada pula lembaga tingkat nasional yang mendukung lembaga keuangan syariah, antara lain : Dewan Syariah Nasional (DSN). DSN didirikan oleh Majelis Ulama Indonesia melalui SKMUI no.kep754/II/99. DSN memiliki badan terafiliasi dalam setiap lembaga keuangan syariah yang terdiri dari atas pakar di bidang perbankan syariah yang bertugas benerbitkan laporan untuk menjamin bahwa bank syariah tersebut telah mematuhi semua prinsip etika bisnis syariah. Berdasarkan surat edaran bank indonesia nomor 8/19/DPBs tahun 2006 tentang pedoman pengawas syariah dan tatakelola pelaporan hasil pengawasan bagi dewan pengawas syariah maka kewajiban Dewan Pengawas Syariah (DPS) adalah sebagai berikut $^{18}$ :

\section{a. Transaksi Mudharabah}

1. Meneliti apakah pemberian informasi secara lengkap telah disampaikan oleh bank kepada nasabah secara tertulis maupun lisan mengenai persyaratan investasi Mudharabah;

2. Menguji apakah perhitungan bagihasil telah dilaksanakan sesuai prinsip syariah;

3. Memastikan adanya persetujuan dalam perjanjian investasi Mudharabah;

4. Memastikan terpenuhinya syarat dan rukun Mudharabah;

5. Memastikan bahwa kegiatan investasi tidak bertentangan dengan syariah.

b. Transaksi Musyarakah

1. Meneliti apakah pemberian informasi secara lengkap telah disampaikan oleh bank kepada nasabah secara tertulis maupun lisan mengenai persyaratan investasi Musyarakah;

2. Menguji apakah perhitungan bagihasil telah dilaksanakan sesuai prinsip syariah;

3. Memastikan adanya persetujuan dalam perjanjian investasi Musyarakah;

4. Memastikan terpenuhinya syarat dan rukun Musyarakah;

5. Memastikan bahwa biaya operasional telah dibebankan bersama modal bersama Musyarakah;

6. Memastikan bahwa kegiatan investasi tidak bertentangan dengan syariah.

c. Transaksi Murabahah

1. Memastikan barang yang diperjual belikan tidak haram; 
2. Memastikan bank menjual barang tersebut kepada nasabah dengan harga jual senilai harga beli plus margin;

3. Meneliti apakah akad wakalah telah dibuat oleh bank secara terpisah dari akad Murabahah;

4. Meneliti pembiayaan berdasarkan prinsip murabahah dilakukan setelah adanya permohonan nasabah dan perjanjian pembelian suatu barang atas suatu aset kepada bank.

d. Transaksi Salam dan Salam paralel

1. Memastikan barang yang dijual tidak haram;

2. Memastikan bayaran atas barang salam kepada pemasok telah dilakukan diawal kontrak secara tunai sebesar akad salam;

3. Meneliti bahwa akad salam telah sesuai dengan fatwa DSN-MUI;

4. Meneliti kejelasan akad salam yang dilakukan dalam format salam paralel atau akad salam biasa;

5. Meneliti bahwa keuntungan bank syariah aatas praktek salam paralel diperoleh dari selisih antara harga beli dan dari pemasok dengan harga jual kepada nasabah/ pembeli akhir.

e. Transakasi istishna' dan istishna paralel

1. Memastikan barang tidak haram;

2. Meneliti apakah bank membiayai pembuatan barang yang diperlukan nasabah sesuai pesanan dan kriteria yang telah disepakati;

3. Memastikan bahwa akad istishna dan akad istishna paralel dibuat dalam akad yang terpisah;

4. Memastikan bahwa akad istishna yang sudah dikerjaan sesuai kesepakatan hukumnya mengikat.

f. Transaksi Ijarah dan IMBT

1. Memastikan penyaluran dana berdasarkan prinsip ijarah tidak dipengaruhi untuk kegiatan yang bertentangan dengan prinsip syariah;

2. Memastikan bahwa akad pengalihan kepemilikan dalam IMBT dilakukan setelah akad ijarah selesai, dan dalam akad ijarah, janji (wa'ad) untuk pengalihan kepemilikan harus dilakukan saat berakhirnya ijarah;

3. Meneliti pembiayaan berdasarkan prinsip ijarah;

4. Memastikan besar ijarah dengan menggunakan akad ijarah telah disepakati diawal dalam bentuk nominal bukan presentase.

g. Transaksi pinjaman Qardh

1. Meneliti apakah pembiayaan yang diberikan berdasarkan prinip qardh;

2. Meneiti bahwa nasabah yang terkena sanksi denda adalah nasabah yang benarbenar lalai;

3. Memastikan bahwa bank telah memberikan kelonggaran waktu yang cukup kepada nasabah tersebut untuk melunasi kewajibannya apabila mengalami penurunan usaha;

4. Meneliti apakah pendapatan yang diterima bank dari nasabah atas pengenaan sanksi telah diaki sebagai sumber dana kebajikan;

5. Memastikan sumberdana yang digunakan untuk pembiayaan qardh konsumtif dan bersifat sosial;

6. Memastikan bahwa sumber dana yang digunakan untuk pembiayaan qardh dalam rangka dana talangan nasabah adalah berasal dari modal bank. 
Mekanisme pengawasan syariah lainnya adalah audit syariah. Kegiatan ini dilakukan oleh unit audit internal perusahaan secara rutin untuk meyakinkan bahwa semua transaksi yang telah dilakukan oleh bank syariah telah memenuhi prinsip etika bisnis islam dan peraturan yang ditetapkan oleh Dewan Pengawas Syariah (DPS). ${ }^{19}$

Dalam pandangan Yaya, Martawireja, dan Abdurahim ${ }^{20}$, Dewan Syariah Nasional (DSN) memiliki badan terafiliasi dalam setiap lembaga keuangan syariah yang dinamakan Dewan Pengawas Syariah yang terdiri atas para pakar di bidang perbankan syariah yang bertugas menerbitkan laporan untuk menjamin bahwa bank syariah tersebut telah mematuhi semua prinsip etika bisnis syariah, dan laporan Dewan Pengawas Syariah tersebut pada umumnya merupakan bagian takterpisahkan dari laporan keuangan auditan bank syariah. Menurut Grais dan Pellegrini ${ }^{21}$ (2006), peran penting dewan pengawas syariah antara lain adalah menyertifikasi instrumen keuangan yang diijinkan oleh fatwa Dewan Syariah Nasional; memverifikasi transaksi apakah telah sesuai dengan fatwa Dewan Syariah Nasional (DSN); menghitung dan membayarkan zakat bank syariah; membuang pendapatan yang tidak sesuai dengan prinsip etika bisnis Islam; dan memberikan saran distribusi pendapatan atau beban diantara pemegang saham dan investor.

\section{KESIMPULAN}

Perbankan syariah hendaknya segara menerapkan etika bisnis syariah secara konsisten pada setiap sistem dan aplikasi transaksi baik dalam kontrak, akad, dan objek pembiayaan. Sebab, bila lembaga tersebut menerapkan etika yang bertolak belakang dengan prinsip-prinsip syariah, maka akan memperburuk citra lembaga, keuangan dan sistem yang di kelola dan menimbulkan krisis kepercayaan dan satispaction atau pernyataan apresiasi dari para pengguna yang mayoritas muslim. Membutuhkan komitmen dan konsistensi dalam melaksanakan kegiatan operasi yang sesuai prinsip etika bisnis Islam, agar dapat memberikan timbal balik yang signifikan dalam perkembangan ekonomi syariah di lingkungan masyarakat untuk menghadapi setiap tantangan masa kini dan masa mendatang dalam memnuhi kebutuhan umat Islam.

Apa bila suatu bank syariah mampu membuat pengungkapan etis secara memadai, itu arinya bank syariah tersebut telah mamapu menciptakan dan menjalankan Standar Oprasional Prosedur (SOP) yang baik dan sehat, baik dalam penerapan etika bisnis Islam dalam kegiatan oprasional kegiatan oraganisasinya, baik di tingkat manajemen maupun Sumber Daya Insani nya. Hal ini tentu saja akan membawa dampak positif bagi industri perbankan syariah seperti peningkatan satispaction (kepuasan), komitmen kerjasama, dan rasa percaya dari para pihak yang berkepentingan.

\section{Andnote/Referensi :}

${ }^{1}$ Dikeluarkan oleh Al-Bukhari dalam Shahihnya:Adab/39, 7/82. Muslim dalam Shahihnya: Al-Fadhail/16, hadits (68), 4/1810.

${ }^{2}$ Firtri Amalia, Etika Bisnis Islam: Konsep dan Implementasi pada Pelaku Usaha Kecil , Al-Iqtishad: Junal Ilmu Ekonomi Syariah 6 (1), 133-142, 2014

${ }^{3}$ Elida Elfi Barus, Nuriani, Implementasi Etika Bisnis Islam “Studi Pada Rumah Makn Wong Solo Medan”, Jurnal Perspektif Darussalam, Vol,2 (2) September 2016, 126

4 Abdul Hamid, Muhammad Kamal Zubair, “ Implementasi Etika Islam Dalam Pemasaran Produk Bank Syariah, Jurnal Balanca, Vol,1 (1) Januari-Juni, 2019,17. 
${ }^{5}$ Ekawati Rahayu Ningsih, " Studi Eksplorasi Penerapan Etika Bisnis Pada Perbankan Syariah di Indonesia, Jurnal Kajian dan Bisnis Islam, Vol,10 (1), 2017, 3

${ }^{6}$ Hafiz Zuliansyah, “ Faktor-Faktor Yang Mempengaruhi Etika Bisnis Islam Pedang Pasar Ciputat, UIN Syarif Hidayatullah, Jakarta, 2011, 17

${ }^{7}$ Perkataan Imam Al-Qurthubi yang dinukil oleh Ibnu Hajar Al-Asqalani di dalam kitabnya Fathul Bari: 1/456.) di download pada: https://id.wikipedia,org/wiki/imam_al-qurthubi

${ }^{8}$ Galuh Anggraeny, Pembelajaran dan Implementasi Etika Bisnis Islam, Jounal Of Multidiscplinary Studies, Vol, 1 (2), Juli-Desember 2017, 233-235.

${ }^{9}$ Dikeluarkan oleh Al-Bukhari dalam Shahihnya:Adab/39, 7/82. Muslim dalam Shahihnya: Al-Fadhail/16, hadits (68), 4/1810.)

${ }^{10}$ Sahih, dikeluarkan Abu Dawud (4682), At-Tirmidzi (1162)

${ }^{11}$ Hadist Riwayat At-Tirmidzi (1987) dan Ahmad (4/153, 158, 236)

${ }^{12}$ Fitri Amalia, Implementasi Etika Bisnis Islam Pada Pedagang Di Bazar Madinah Depok, Prosiding Seminas Competitive Advantage, Jorunal Uinpdu, Vol 1 (2), 2012

${ }^{13}$ Fitri Amalia, Etika Bisnis Islam: Konsep dan Implementasi pada Pelaku Usaha Kecil , Al-Iqtishad: Junal Ilmu Ekonomi Syariah 6 (1), 2014, 133-142.

${ }^{14}$ Sri Nawatmi, Etika Bisnis Dalam Perspektif Islam, Fokus Ekonomi (FE), Vol 9 (1) April 2010, 50 - 58

${ }^{15}$ Afrida Putritama, "Penerapan Eetika Bisnis Iislam Dalam Industri Perbankan Syariah (The Application Of Islamic Business Ethics In Islamic Banking ), Jurnal Nominal, Vol ,7 (1) ,2018, 1-20

${ }^{16}$ Yaya, Rizal; Martawireja, Aji Erlangga; Abdurahim, Ahim. (2013) Akuntansi Perbankan Syariah: Teori dan Praktik Kontemporer. Jakarta: Salemba Empat

${ }^{17}$ Afrida Putritama, "Penerapan Eetika Bisnis Iislam Dalam Industri Perbankan Syariah (The Application Of Islamic Business Ethics In Islamic Banking ), Jurnal Nominal, Vol ,7 (1) ,2018, 1-20

${ }^{18}$ Ibid, 8

${ }^{19}$ Ibid, 10

${ }^{20}$ Yaya, Rizal; Martawireja, Aji Erlangga; Abdurahim, Ahim. (2013) Akuntansi Perbankan Syariah: Teori dan Praktik Kontemporer. Jakarta: Salemba Empat

${ }^{21}$ Grais, Wafik and Pellegrini, Matteo. (2006) "Corporate Governance and Shariah Compliance in Institutions Offering Islamic Financial Services”. World Bank Policy Research Working Paper, 4054. 